\title{
Adult Acute Promyelocytic Leukemia with PML-RARA
}

National Cancer Institute

\section{Source}

National Cancer Institute. Adult Acute Promyelocytic Leukemia with PML-RARA. NCI

Thesaurus. Code C9155.

An acute promyelocytic leukemia with PML-RARA fusion occurring in adults. 